\title{
The Politico-Economic Competition Affecting Ecotourism Development in Serengeti-Mara Ecosystem between Kenya and Tanzania
}

\author{
Dr. Godfrey Cotty Ungaya \\ Department of Political Science and Peace Studies, Kisii University, Kisii Town, Kenya \\ E-mail Address: godfreycotty@kisiiuniversity.ac.ke \\ DOI: 10.31364/SCIRJ/v9.i02.2021.P0221839 \\ http://dx.doi.org/10.31364/SCIRJ/v9.i02.2021.P0221839
}

\begin{abstract}
The purpose of this paper is to analyze the politics around revenue sharing dilemma which affects ecotourism development in Serengeti-Mara ecosystem between Kenya and Tanzania. Ecotourism is a form of tourism that is geared towards conservation of tourist destinations as opposed to traditional tourism of profit maximization from tourism activities by key stakeholders. The EAC Regional Tourism policy forms the foundation of ecotourism development in this transboundary ecosystem. Despite existence of this agreement, ecotourism development has been negatively affected by the politics of revenue sharing accrued from tourism activities among key players on both sides of the border. The study used questionnaire, interviews and focused group discussion to collect primary data while secondary data were collected using journals, documents, acts, legislations, sessional papers and conventions/protocols on tourism. Data were analyzed using descriptive statistics. The qualitative data were analysed by consolidating emerging themes from the key informant interviews and topic analysis. Quantitative data were analysed using descriptive statistics such as frequencies and percentages. Data were presented in form of tables, pie charts and narrations. The results indicate issues of revenue sharing are yet to be sorted which has affected ecotourism in terms of tourist flow and conservation of this tourist destination. Findings demonstrate that Maasai Mara National Reserve receives 290,000 against Serengeti 116,000 foreign tourists annually. But a look at international receipts show that Serengeti revenue collection is more than Mara's. Thus, lack of concrete structures on how to increase revenue generation and sharing within the EAC tourism policy has led to political and economic competition in this transboundary ecosystem. There is need for review of the EAC tourism policy such that the political and economic competition between the two nation-states is removed.
\end{abstract}

\section{Key words: Revenue Sharing, Profit Maximization, Conventions, Transboundary, Ecotourism and Ecosystem}

\section{Introduction}

In the Serengeti Mara ecosystem, ecotourism development has largely been affected by statist tourism policies despite the existence of a regional tourism policy. This means that regional cooperation on policy coordination is minimal or lacking totally in some aspects of ecotourism. In previous studies, the focus has not been on the sub-field of international political economy but on collaborative natural resource management with view of forestalling conflict among the partner states (Omar, 2013). As much as Omar study is relevant to the current one since it highlights the importance of regional policy in solving cross border conflict on natural resources, his study is focused on conflict over transboundary natural resources and not politico-economic competition that affects ecotourism development in Serengeti-Mara.

A study by IGAD in this academic field has been on ecotourism development in individual states (IGAD, 2011).The gaps in these studies is that they have not in any way explored how diplomacy can be utilized to reduce issues of international political economy with focus on ecotourism development. Therefore, previous studies on the EAC regional policy coordination have not 
been sufficiently studied in Serengeti-Mara ecosystem in relation to politico-economic aspects that affect ecotourism development.

The problem is that the EAC regional tourism policy is weak and thus no much study has been undertaken to address international political economy issues that emerge due to shortcomings in the regional tourism policy with regard to ecotourism development in shared ecosystems like Serengeti-Mara. The ease of access of tourists to tourist sites; and community development ecotourism sites are core of ecotourism. On this, tourism flow between the two adjacent parks is negatively affected by Kenya and Tanzania 1983 bilateral agreement that stipulated that tour vans are barred from entering each other's borders and that designated border towns serve as entry points in this shared ecosystem (Republic of Kenya and Tanzania, 1983). Additionally, despite the EAC common tourist visa existence, the policy is yet to facilitate an open air mechanism in the region. Therefore, political and economic competitions between the two states are a result of a weak regional tourism policy.

\section{Materials}

The Serengeti-Mara Ecosystem is an area of some $25000 \mathrm{~km}$ spanning the border between Tanzania and Kenya (34-36 degrees East, 1-3 degrees, 30's). The Kenyan part of the ecosystem lies in the South-West of the Nakuru County, forming part of two sub-counties, Narok and Trans Mara. It comprises approximately $6000 \mathrm{~km}$ of which 25\% represents Maasai Mara National Reserve and $75 \%$ unprotected land inhibited by Maasai and other agro-pastoral communities (Malt, 2003). The Maasai Mara National Reserve and adjoining group ranches in Kenya form the northern portion of the Serengeti-Mara ecosystem to which wild animals, especially wildebeest and zebra migrate annually. The wildebeest and zebra from Serengeti National Park migrate and stay in the Maasai Mara ecosystem between June and November (Omar, 2013). However, issues of revenue sharing are a concern among stakeholders in this ecosystem.

The politics around revenue sharing has affected ecotourism a number of ways. For instance access to tourism sites on either side is made difficult by restrictive nationalistic policies and communities residing around the ecosystem do not fully benefit from revenues generated (LVBC, 2010).

The researcher used interview schedule. The researcher and research assistants spent at least 5 days in each study site to conduct interviews. Both an in-depth formal and informal interviews were done. The formal interviews were structured since they involved a set of questions of predetermined questions. The interview schedule was used with EAC agency directors, Park Managers, directors of KWS, TANAPA and TWS, directors of INGOs and NGOs and tour operators.

Also, Focused Group Discussion was used paying attention on how local communities financially benefit from ecotourism activities. This method was used to probe various aspects of ecotourism activities that Community Based Natural Resource 
Management Groups engage in within dispersal areas of Serengeti Mara ecosystem. Members involved in this included heads of conservancies, wildlife management areas and existing community based natural resource management groups in these dispersal areas of the SMME. Lastly, the study relied on secondary data by examining books, reports, journal articles, online materials articles on aspects of ecotourism and bilateral agreement. The researcher sourced secondary data by analysis of publications such as journals on tourism, EAC tourism related legislations and government documents.

\section{Methods}

Qualitative was analysed by way of content analysis. The frequency with which an idea or word or description appears was to interpret the importance, attention or emphasis. Content analysis examined the intensity with which certain words had been used. A classification system was developed to record the information in interpreting results. The frequency with which a symbol or data appeared showed the measure of importance, attention or emphasis. The researcher presented data findings in form of frequency tables, pie charts, bar graphs and narratives.

There were factors that affected the results of the study. One, the researcher was unable to gather information from some respondents who declined to participate or were unavailable for interviews. Also, there were geographical limitations that were experiences due to rough terrain in the wilderness, poor road network and bad weather. Lastly, there was language barrier in the rural areas. To overcome these shortcomings, the researcher engaged a tour guide to interpret and translate questions for the respondents. Further, research assistants from the area were engaged to assist in data collection. The researcher used four wheeled vehicle to overcome geographical limitations.

In addition, the researcher utilized secondary materials from EAC Ministry, EAC agencies, Kenya Tourism Board and Tanzania Tourism Corporation and other institutions that had previously studied this ecosystems tourism status. On language barrier, the researcher engaged an interpreter to explain and interpret for the respondents.

\section{Findings and Discussions}

\section{Politico-economic Barriers to Ecotourism Development}

To find out specific political, socio-economic and governance obstacles to greater revenue sharing, the researcher asked park managers, tourism officers in Ministries of EAC and Tourism, directors/managers of EAC tourism agencies, KWS, TANAPA, TWS to identify political, socio-economic and organization governance barriers of tourism policy coordination on revenue sharing in SMME. The total number of respondents was 10. Two questionnaires were not returned. (Table 1 here) 
Table 1 indicates that $4(50 \%)$ of the respondents agree that political factors are a hindrance to tourism policy coordination action while $3(37.5 \%)$ argued to socio-economic factors. Findings indicate that $1(12.5 \%)$ argued that organization governance lead to revenue sharing challenges. This means that lack of political will is the main undoing factor with regard to coming up with a revenue sharing mechanisms. Other challenges such as economic could be ironed out politically when organizational structures are put in place. It is through these structures that information sharing and exchange are enabled revenue sharing.

The tourism officer argued that it is through political will that some of these challenges could be sorted out. This finding concurs with an argument that appeared in the Standard on Sunday (2015) that political suspicion and lack of political will to harmonize immigration and road transport policies has made it difficult for tourists to move with ease between the two parks. This was a factor reiterated by foreign tourists who frequent the SMME. The issue is that tour operators in Serengeti earn more from tourism activities than their Kenyan counterparts. In an interview (2), a park manager (b) said:

Tourism fee charges in Mara are not competitive in comparison to Serengeti's. A foreign tourist pays almost three times for same services in lodges and camps in Serengeti (Interview with a tourist, held on March, $29^{\text {th }}$ 2018 in Serengeti National Park).

This assertion confirms that lack of interlinked roads/air lines within the SMME is as a result of perceived loss of revenue by stakeholders who include tour operators and respective state government. This result concurs with Manyara (2009) assertion that economic inequality is a challenge. But these findings go against his assertion that the dollar does not cross the border to Tanzania. In his study, he alleges that the Kenyan side of SMME earns more revenue as a result of tourism activities. This was not the case since tour operators in Serengeti earn far more revenue in comparison. The findings are best explained by political realist view that lack of an international or regional government creates anarchy which increases political and economic competition among states as registered in Serengeti-Mara ecosystem.

\section{Tourism Revenue Distribution in Mara-Serengeti}

\section{(Table 2 here)}

Table 2 indicates that Maasai Mara National Reserve receives 290,000 against Serengeti 116,000 foreign tourists annually. But a look at international receipts show that Serengeti revenue collection is more than Mara's. This is because a foreign tourist spends more than twice in Serengeti on tourism facilities. Thus, Mara runs on budget tourism; that is high volumes of low paying tourists. This is not the case with Serengeti where low volume and high value brings in more revenue annually comparatively.

The problem is that high volume-low value tourism is not sustainable particularly during low tourism seasons. Further, high volumes of tourists may be detrimental to environmental protection because of pressure to provide more tourist facilities. Kenyan budget tourism promotes traditional mass tourism that goes against aspects of ecotourism on negative environmental impact of tourism activities. This result concur with Lake Victoria Basin Commission report that higher visitation rates in Kenya's national 
parks have also led to negative impacts on the wildlife that is the very drawback for tourists (LVBC, 2010). Such pressure could be off-set by cross border private-public partnership to have more tourist facilities (lodges and camps) in Serengeti as opposed to Mara. But this could only be possible once challenges of revenue distribution are sorted out between the stakeholders. Due to higher operating costs in Tanzania, profits for the tour operator tend to be about the same for both countries. Thus there is skewed revenue distribution even among tour operators in Serengeti Mara.

From this discussion, it is clear that safari multi-destination tour packages and all of the travel arrangements are held from the Nairobi office. Then tours outside Kenya are subcontracted to a partner operator in neighbouring countries. Because SerengetiMara ecosystem is popular with foreign tourists, first-time travellers to the region are often drawn to it. In this context, revenue sharing is an economic issue that needs structured means for equity between stakeholders. In an interview (3), a tourism officer (a) opined:

Almost all safari tours to Serengeti-Mara are planned in Nairobi. Thus, Mara side of the ecosystem is visited first before a tourist goes to Serengeti (Interview held on $3^{\text {rd }}$ May, 2018 at Ministry of Tourism, Nairobi).

This sentiment confirms that Kenya has a comparative advantage over Tanzania because of its facilities and air arrangements for foreign tourist. This assertion concurs with Manyara's (2009) argument that tourists would visit Mara then proceed to Serengeti. But the finding does not agree with his assertion that Mara side reaps more in terms of revenue than Serengeti. Manyara's study failed to indicate that mutual gains cannot be realized in a skewed economic environment unless joint investments are made by concerned parties across the border. As political realists argue, selfish interests in this issue area of ecotourism promote economic competition in Serengeti-Mara.

For example, a premium safari multi-destination tour package a 16-day/14-night full-board package where 50 per cent of the time is spent in Kenya on a wildlife safari in Mara and the remaining time in Serengeti, Tanzania. The package is valued at US $\$ 8,000$ (includes airfare from the United States), and with out-of pocket expenditures, the total value of the tourist expenditure was US\$8,375.69 (Global Development Solutions, 2015).

When this money is spent, there is an imbalance in terms of expenditure in the two countries. For example, although normally the time spent on a tour may be split 50-50 between Kenya and Tanzania, the revenue distribution between the two countries is 35 per cent and 65 per cent, respectively. Thus, it means that only US $\$ 1,954.71$ of the total tourist dollars (US $\$ 8,375.69)$ is used in Kenya (Global Development Solutions, 2015). As indicated earlier, tourists pay more for tourist services in Serengeti than Mara. Thus, the fear of economic loss for tour operators in Serengeti and Tanzanian government in general stems from this notion that linked roads and airlines between the two adjacent parks would automatically favour Kenya tour operators. But park fee is higher in Mara than Serengeti. (Table 3 here) 
Table 3 indicates that tourists pay much more park fees in Mara than Serengeti. A foreign tourists, for instance, pays \$10 dollars more in Mara than in Serengeti. But lodge/camp, conservancy and other fees are much higher in Serengeti than Mara. It is in the camps/lodges that tour operators in Serengeti earn more revenue than their counterparts in Mara. (Tables 4 and 5 here)

Tables 4 and 5 indicate that camping package in Serengeti are almost three times higher than in Mara. Tour operators in Serengeti earn more from tourist activities than their counterparts in Mara. By extension, the revenues collected from foreign tourists are much higher in Tanzania than in Kenya. Therefore, opening the border between the two adjacent parks would lead to competitive tour packages that could result into revenue loss to tour operators on Serengeti.

\section{Challenges in Mara-Serengeti Tourism}

Serengeti underperforms Mara in terms of numbers of tourists but does better in terms of value per tourist. This means that low volume but high value tourism is effective on Serengeti side of SMME. Thus, Serengeti achieves environmental protection by limiting number of tourists compared to Mara. The reverse, however, is that it has constrained the growth and diversification of tourism products and operators beyond the higher premium offers; the policy and existing legislation actually raise barriers to entry for smaller operators in Serengeti. These constraints in tourist products and compromise on service delivery are detrimental to eco-tourist satisfaction in Serengeti.

Findings indicate that Tanzanian safaris in Serengeti are more expensive to operate by between 30-35\% compared to Mara's. Some of the reasons are longer distances and high fuel costs; unreliable and expensive electricity; higher labour costs due in part to lower productivity; higher resupply and repair and maintenance costs in lodges (Global Development Solutions, 2015). With such challenges, tourist access and satisfaction in Serengeti are compromised. To realise this segment of ecotourism, therefore, joint projects with regard to infrastructure between the two states is the way to go. In an interview (1), a park manager (a) said:

Different immigration laws and regulation of Kenya and Tanzania are obstacles to tourist access to tour products (Interview held on $3^{\text {rd }}$ May, 2018 in Maasai Mara National Reserve).

This argument confirms that the political environment influence decision making processes in areas of infrastructural developments and marketing of tourism in the SMME. The laws and regulations that apply to tourism are prohibitive to tourism flow between the two parks because of lack of political will to iron them out. Thus, lack of political will hurts ecotourism development in aspects such as tourist access and awareness of tourism products.

Since the bilateral policy stipulates that tourism activities are subject to laws and custom regulations of contracted parties, therefore, easing tourist flow in SMME is a delusion. Thus, it's through political will that harmonization if this laws and regulation could take place at state-state level. A common outcome of such challenges produced by distinct political organizations is that competition between players in the SMME is order of day and not cooperation.

Such competition would definitely affect tourism flow across the border in SMME. These findings concur with Manyara (2009) argument that tourists visiting Serengeti Mara land at Jomo Kenyatta International Airport. Mara side of the SMME is just 
$10 \%$ of the ecosystem but attracts ten times more foreign tourists that Serengeti. He argues that a possible consequence of such a situation might be that Mara side of SMME developed way a head of Serengeti as a result of capitalist ideological orientation as opposed to socialism in Tanzania. This finding concurs with a LVBC (2010) report that Serengeti is just catching up with Mara in terms of development of tourism infrastructure.

\section{Conclusion}

The politics of revenue sharing has negatively affected ecotourism development in Serengeti-Mara ecosystem. Tour operators in Tanzania would suffer great revenue losses if the borders are open for ease access of tourists on either side of the border. The political will is lacking for more diplomatic talks on how to streamline revenue sharing among tour operators and respective governments of Tanzania and Kenya.

The conclusion is that tourism policy coordination ad hoc, bureaucratic and top down in nature in Serengeti-Mara ecosystem. The main cause of ad hoc coordination is as a result of weak implementation mechanisms at regional or bilateral level to enforce policy coordination. Although the East African Tourism Wildlife Coordination Agency (EATWC) and East African Tourism Wildlife Conservation Agency (EATWCA) are responsible agencies to coordinate policy on marketing at regional and international level and conservation.

Also, extent of policy coordination is limited to international marketing and conservation of wildlife and thus leaves out other pillars of ecotourism. Consequently, policy coordination is majorly dependent on state agencies such as KWS, TWS/TANAPA or Narok County government (Kenyan side). The 1983 bilateral agreement between Kenya and Tanzania overrides regional policy agreement in areas of tourism. The bilateral agreement is statist in that it empowers state agencies/parastatals with function of tourism policy coordination. Diplomatic engagement between the two-nation-states need to relook at the bilateral policy of 1983 and fully adopt the EAC tourism policy.

\section{Acknowledgements}

First, I thank the Almighty God who gave me the physical and mental endurance to undertake this study. In addition, the accomplishment of this degree would not have been possible without the support and guidance of some people. I would like to express my sincere gratitude to everyone who helped me through this immense task. My utmost debt of gratitude goes to my two supervisors: Professor Pontian Godfrey Okoth and Professor Edmond Maloba Were, whose guidance and support saw the development and perfection of this academic work. I also wish to express my gratitude to Mr. Laban Mulehi and Mrs. Patricia Njeru of Narok County, Julius Mamati of Maasai Mara University, Jackson Ambani of the Ministry of EAC and other respondents who spared their time to respond to my questions. 


\section{References}

IGAD (2011). Environmental Outlook: Our Environment, Our wealth

LVBC. (2010). Lake Victoria Basin Commission's Operational Strategy 2007 to 2010. . Kisumu, Kenya: Lake Victoria Basin Commission

Manyara, G. (2009). Investment in indigenous tourism enterprises in sub-Saharan Africa:. Challenges and opportunities for policy considerations, $90-95$

Matt, W. (2003). Conflict and Conservation in Maasai Mara, Kenya,'. Nairobi: International Institute for Environment and Development.

Omar, H. (2013). The implications of the shared natural resources on interstate Relations in the east African community: A case study of Maasai/serengeti national parks,. Nairobi: University of Nairobi Press.

The Standard on Sunday. (2015). Kenya gives Tanzania two weeks to resolve tour vans dispute Bad brother: Kenyan tourist vans are not allowed into Tanzania, but Kenya had no similar restrictions on their Tanzanian counterparts. Nairobi.

Global Development Solutions, LLC. (2015). Integrated Value Chain Analysis of the Tourism Sector in Kenya Prepared for The World Bank, 11921 Freedom Drive Suite 550 Reston, VA. 20190.

Table 1: Political, Socio-economic Challenges to Policy Coordination in SMME

\begin{tabular}{|c|c|c|c|c|c|}
\hline \multirow[b]{2}{*}{ Valid } & & \multirow{2}{*}{$\begin{array}{r}\text { Frequency } \\
4 \\
4\end{array}$} & \multirow{2}{*}{$\begin{array}{r}\text { Percent } \\
\\
50.0\end{array}$} & \multirow{2}{*}{$\begin{array}{l}\text { Valid Percent } \\
50.0\end{array}$} & \multirow{2}{*}{$\begin{array}{l}\text { Cumulative } \\
\text { Percent } \\
50.0\end{array}$} \\
\hline & Political & & & & \\
\hline & Socio-economic & 3 & 37.5 & 37.5 & 87.5 \\
\hline & $\begin{array}{l}\text { Organization and } \\
\text { governance }\end{array}$ & 1 & 12.5 & 12.5 & 100.0 \\
\hline & Total & 8 & 100.0 & 100.0 & \\
\hline
\end{tabular}

Source: Field Data, 2018

Table 2: Annual Revenue Collection in Serengeti-Mara Ecosystem, 2015

\begin{tabular}{llc}
\hline Country & International Receipts & International Arrivals \\
\hline Kenya (Mara) & $\$ 294 \mathrm{~m}$ & 290,000 \\
Tanzania (Serengeti) & $\$ 344.8 \mathrm{~m}$ & 116,000
\end{tabular}

\section{Source: Stanbic Investment Services, 2015}

WWW.scirj.org

(C) 2021, Scientific Research Journal

http://dx.doi.org/10.31364/SCIRJ/v9.i02.2021.P0221839

This publication is licensed under Creative Commons Attribution CC BY. 
Table 3: Serengeti-Mara Park Fees for Tourists per Day, 2017-2018

\begin{tabular}{lccc}
\hline SERENGETI & Non-residents & EAC Residents & EAC Citizens \\
\hline Adult & $\$ 60$ & $\$ 40$ & $\$ 40$ \\
Children & $\$ 20$ & $\$ 0.8$ & $\$ 0.8$ \\
Student & $\$ 20$ & $\$ 0.8$ & $\$ 0.8$ \\
\hline MARA & $\$ 70$ & $\$ 12$ & $\$ 10$ \\
\hline Adult & $\$ 40$ & $\$ 3$ & $\$ 2$ \\
Children & $\$ 40$ & $\$ 3$ & $\$ 2$ \\
\hline Student & & & \\
\hline
\end{tabular}

Source: Field Data, 2018

Table4: Bush Rover Serengeti Migration Camp Fees for Tourists, 2017-2018

\begin{tabular}{lll}
\hline & Per Person & Single Occupancy \\
\hline Full Package Rack (Twin/Double) & $\$ 495$ & $\$ 690$ \\
Game Package Rack (Twin) & $\$ 615$ & $\$ 810$ \\
\hline
\end{tabular}

Source: Field Data, 2018

Table 5: Camp Fees for Tourism at Siana Conservancy in Mara, 2017-2018

\begin{tabular}{lll}
\hline & Per Person & Single Occupancy \\
\hline Full Package Rack (Twin) & $\$ 145$ & $\$ 406$ \\
Game Package Rack (Twin) & $\$ 225$ & $\$ 630$
\end{tabular}

Source: Field Data, 2018 